\title{
Life cycle impacts of topsoil erosion on aquatic biota: case study on Eucalyptus globulus forest
}

\author{
Paula Quinteiro ${ }^{1}$ - Marijn Van de Broek ${ }^{2}$ • Ana Cláudia Dias ${ }^{1}$ - Bradley G. Ridoutt ${ }^{3,4}$ • \\ Gerard Govers $^{2} \cdot$ Luís Arroja $^{1}$
}

Received: 31 July 2015 / Accepted: 2 June 2016

(C) Springer-Verlag Berlin Heidelberg 2016

\begin{abstract}
Purpose This study illustrates the applicability of a framework to conduct a spatially distributed inventory of suspended solids (SS) delivery to freshwater streams combined with a method to derive site-specific characterisation factors for endpoint damage on aquatic ecosystem diversity. A case study on Eucalyptus globulus stands located in Portugal was selected as an example of a land-based system. The main goal was to assess the relevance of SS delivery to freshwater streams, providing a more comprehensive assessment of the SS impact from land use systems on aquatic environments.

Methods The WaTEM/SEDEM model, which was used to perform the SS inventory, is a raster-based empirical erosion and deposition model. This model allowed to predict the
\end{abstract}

Responsible editor: Miguel Brandão

Electronic supplementary material The online version of this article (doi:10.1007/s11367-016-1146-1) contains supplementary material, which is available to authorized users.

Paula Quinteiro

p.sofia@ua.pt

1 Centre for Environmental and Marine Studies (CESAM), Department of Environment and Planning, University of Aveiro, Campus Universitário de Santiago, 3810-193 Aveiro, Portugal

2 Division of Geography, Katholieke Universiteit Leuven, Celestijnenlaan 200E, 3000 Leuven, Belgium

3 Commonwealth Scientific and Industrial Research Organisation (CSIRO), Private Bag 10, Clayton South, Victoria 3169, Australia

4 Department of Agricultural Economics, University of the Free State, Bloemfontein 9300, South Africa amount of SS from E. globulus stands under study and route this amount through the landscape towards the drainage network. Combining the spatially explicit SS inventory with the derived site-specific endpoint characterisation factors of SS delivered to two different river sections, the potential damages of SS on macroinvertebrates, algae and macrophytes were assessed. In addition, this damage was compared with the damage obtained with the commonly used ecosystem impact categories of the ReCiPe method.

Results and discussion The relevance of the impact from SS delivery to freshwater streams is shown, providing a more comprehensive assessment of the SS impact from land use systems on aquatic environments. The SS impacts ranged from 15.5 to 1234.9 PDF $\mathrm{m}^{3}$.yr.ha ${ }^{-1}$.revolution ${ }^{-1}$ for macroinvertebrates, and from 5.2 to 411.9 PDF. $\mathrm{m}^{3}$.yr.ha ${ }^{-1}$.revolution ${ }^{-1}$ for algae and macrophytes.

For some stands, SS potential impacts on macroinvertebrates have the same order of magnitude than freshwater eutrophication, freshwater ecotoxicity, terrestrial ecotoxicity and terrestrial acidification impacts. For algae and macrophytes, most of the stands present SS impacts of the same order of magnitude as terrestrial ecotoxicity, one order of magnitude higher than freshwater eutrophication and two orders of magnitude lower than freshwater ecotoxicity and terrestrial acidification.

Conclusions The SS impact results allow concluding that the increase of SS in the water column can cause biodiversity damage and that the calculated impacts can have a similar or even higher contribution to the total environmental impact than the commonly used ecosystem impact categories of the ReCiPe method. A wide application of the framework and method developed at a local scale will enable the establishment of a regionalised SS inventory database and a deep characterisation of the potential environmental impacts of SS on local aquatic environments. 
Keywords Algae and macrophytes · Eucalyptus globulus . Land use $\cdot$ Life cycle assessment $\cdot$ Macroinvertebrates . Suspended solids · Topsoil erosion · WaTEM/SEDEM model

\section{Introduction}

Topsoil erosion leads to changes on soil properties and to the displacement of suspended solids (SS) towards the surfacewater systems. Figure 1 (based on Quinteiro et al. 2014, 2015a) illustrates the potential environmental pathways related to topsoil erosion. The loss of topsoil can lead to a loss of productive capability of land, and this has begun to be considered recently in LCA studies in the context of terrestrial ecosystem services (e.g. Núñez et al. 2012; Saad et al. 2013). Topsoil erosion leads to the degradation of soil quality, leading to the loss of essential plant nutrients and reduction of soil depth. This pathway points to a decrease of biomass productivity, affecting the biodiversity of terrestrial ecosystems. Furthermore, topsoil erosion can change soil productivity, leading to a reduction in food availability, which, in turn, can result in malnutrition or undernutrition in developing countries, generating impacts on human health (Núñez et al. 2012)

However, displaced soil is itself a source of potential environmental harm, especially when it reaches water systems. High concentrations of SS reaching lotic environments and remaining in suspension can be significant stressors to the biodiversity of these aquatic systems, causing major disruptions in the aquatic ecosystems, leading to sub-lethal and lethal effects on macroinvertebrates, primary producers (e.g. algae and macrophytes) and fish communities (Angermeier et al. 2004; Bilotta and Brazier 2008; Collins et al. 2011; Quinteiro et al. 2015a). The presence of high concentrations of SS due to topsoil erosion by water affects macroinvertebrates by clogging feeding structures and damaging gills and digestive structures (Bilotta and Brazier 2008). Also, algae and macrophytes can be affected by high concentrations of SS, which reduce the required light penetration through the water column for photosynthesis purposes and also cause damage by abrading the photosynthetic parts of algae (Parkhill and Gulliver 2002; Allan and Castillo 2007; Luce et al. 2010). Fish communities are affected due to the abrasion and the clogging of fish gills (Richardson and Jowett 2002; Kefford et al. 2010). As a result of human-induced climate change, the frequency and intensity of seasonal heavy precipitation events have been increasing in a broad range of worldwide areas (IPCC 2007; Lima et al. 2013), which in combination with high soil erodibility and steep slopes of land use production systems (both agro- and forest ecosystems) and anthropogenic activities can result to significant loss of soil (Pimentel et al. 1995; Grimm et al. 2002; FAO 2013).
Life cycle assessment (LCA) is a methodology that assesses the environmental impacts of products and organisations (ISO 2006a) and is being used to support decision-making, ecolabelling schemes and environmental product declarations (JRC-IES 2012), among other applications. A more comprehensive impact assessment can be achieved by including additional types of environmental impacts beyond the commonly used impact categories in the LCA context (e.g. climate change, eutrophication and acidification). Several efforts have been undertaken to consider the damage of land use and land use changes on terrestrial biodiversity (Geyer et al. 2010a, b; Koellner and Scholz 2007; Koellner et al. 2012, 2013; Michelsen 2008; Schmidt 2008) and ecosystem services (Brandão and Milà i Canals 2013; Beck et al. 2011; Milà i Canals et al. 2007, 2012; Núñez et al. 2012; Reinhard and Zah 2009; Saad et al. 2011, 2013) (e.g. biomass production and freshwater filtration). However, less attention has been paid to potential impacts of SS from topsoil erosion on aquatic biota, mainly because of the complexity of establishing a spatial inventory of eroded SS from upland sources. Recently, Quinteiro et al. (2014, 2015a) developed a framework to construct inventories of both soil erosion and SS delivery to aquatic systems using a spatially distributed soil and SS delivery model (WaTEM/SEDEM) (Van Oost et al. 2000; Van Rompaey et al. 2001; Verstraeten et al. 2002) and proposed a method to derive regional characterisation factors for endpoint damage on aquatic ecosystem diversity (macroinvertebrates, algae and macrophytes).

This study illustrates the applicability of the framework and method proposed by Quinteiro et al. (2014, 2015a) by performing a case study on a land use system of Eucalyptus globulus stands, which is often located on steep slopes, being susceptible to soil erosion. A spatially explicit inventory of sources of SS and their potential impact on aquatic biota is of paramount importance, given the spatial heterogeneity of soil erodibility (Panagos et al. 2014), topography and rainfall erosivity (Diodato and Bellocchi 2010) at the catchment scale.

The relevance of SS delivery to freshwater streams was assessed, providing a more comprehensive assessment of the SS impact from land use systems on aquatic environments. Also, to understand the contribution of SS to the overall environmental impacts, the damage resulting from additional SS input to the water column was compared with the damage obtained from the commonly used ecosystem impact categories of the ReCiPe method.

\section{Methods}

\subsection{Scope}

This study considers four E. globulus stands located in the Central interior region of Portugal. Table 1 presents the site- 


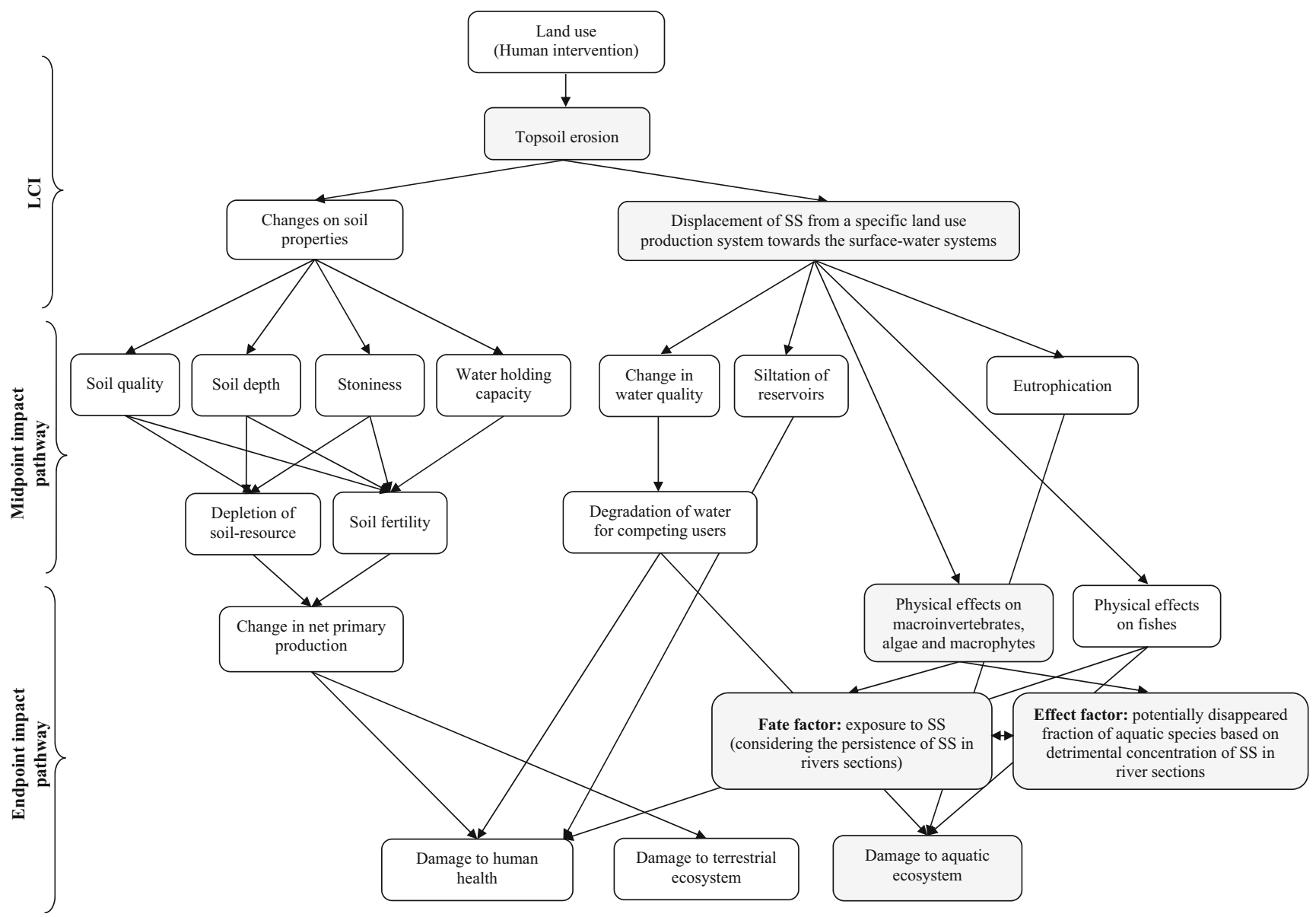

Fig. 1 Potential environmental impact pathways related to topsoil erosion. The shaded boxes relate to the pathway focused on this study

specific soil characteristics on which the SS inventory is strongly dependent and area of the four stands. The E. globulus was chosen for assessment because it is one of the most abundant forest species in Portugal, covering $26 \%$ $(812,000 \mathrm{ha})$ of the total forest area (ICNF 2013). Almost one third of the Portuguese territory, including the Central interior region, is at high risk of erosion by water (Grimm et al. 2002). The Central interior region, particularly the lower-middle watershed of Tagus river (Electronic Supplementary Material, Fig. S1), has a very weakly developed mineral soil layer in unconsolidated material classified as Regosols (European Commission 2005), which, in combination with outbreaks of rain after frequent dry periods, make most of the sloping areas within this region prone to erosion (Grimm et al. 2002; Panagos et al. 2014). E. globulus stands are mainly used for pulp and paper production and are managed as a coppiced stand in short rotations of typically 12 years each, during three successive coppice rotations over one revolution (from site preparation to final cutting -36 years).

Table 1 SS produced and delivered to the Tagus river sections during one revolution of E. globulus and site-specific soil characteristics (K (soil erodibility) and LS (slope length) parameters) on which the SS inventory is strongly dependent

\begin{tabular}{llllll}
\hline & $\begin{array}{l}\text { Tagus river } \\
\text { section }\end{array}$ & Area (ha) & $\begin{array}{l}\text { SS delivery to Tagus river } \\
\left(\mathrm{t} \cdot \mathrm{ha}^{-1} \text {.revolution }\right.\end{array}$ & $\begin{array}{l}\text { Average K parameter } \\
\left.\text { (t.ha.h.ha }{ }^{-1} . \mathrm{MJ}^{-1} \cdot \mathrm{mm}^{-1}\right)\end{array}$ & $\begin{array}{l}\text { Average LS parameter } \\
(\text { dimensionless })\end{array}$ \\
\hline Stand 1 & Almourol & 8.2 & 4.1 & 0.029 & 1.34 \\
Stand 2 & & 29 & 329.0 & 0.037 & 10.27 \\
Stand 3 & Vila Velha & 83 & 147.6 & 0.038 & 16.27 \\
Stand 4 & de Rodão & 103 & 131.6 & 0.040 & 7.02 \\
\hline
\end{tabular}


The functional unit (FU) was defined as 1 ha of E. globulus managed forest over one revolution.

\subsection{SS inventory}

The life cycle inventory of SS originating from soil erosion in E. globulus stands was performed by applying the WaTEM/ SEDEM model (Van Oost et al. 2000; Van Rompaey et al. 2001; Verstraeten et al. 2002). This model predicts the spatial distribution of long-term mean annual soil loss by sheet, rill and ephemeral gully erosion (Desmet and Govers 1996a) and SS delivery at the catchment scale. The amount of eroded soil is calculated using the empirical RUSLE (Renard et al. 1997) and routed through the landscape using the fluxdecomposition algorithm (Desmet and Govers 1996b), and soil particles are deposited in cells where the transport capacity is exceeded (Desmet and Govers 1995; Van Oost et al. 2000; Van Rompaey et al. 2001).

In a first step, eroded soil transport in the WaTEM/SEDEM model has to be constrained by selecting adequate transport capacity coefficients $(\mathrm{ktc})$. The ktc values represent the slope length needed to produce the amount of soil equal to the transport capacity from a bare surface with the local slope gradient (Van Rompaey et al. 2001). Due to a lack of an extensive dataset of measurements, the most adequate ktc values were selected based on existing literature. In a second step, the sensitivity of the model results to the ktc values was evaluated. Subsequently, model performance using the optimal set input parameters was validated against SS measurements in the main river channel. In a last step, the model was used to calculate the SS delivery from the four E. globulus stands towards the main river channel.

\subsubsection{WaTEM/SEDEM model calibration}

WaTEM/SEDEM (Van Oost et al. 2000; Van Rompaey et al. 2001; Verstraeten et al. 2002) is a raster-based empirical erosion and deposition model. For every grid cell, the amount of eroded soil is calculated based on the RUSLE (Renard et al. 1997) and is subsequently routed through the landscape. When the total amount of soil in a grid cell exceeds the runoff transport capacity, the amount of material leaving the grid cell equals the runoff transport capacity, and the remaining part of the material is deposited in that grid cell. The runoff transport capacity (Tc) (Van Rompaey et al. 2001) is proportional to the potential gully erosion as shown in Eq. 1.

$\mathrm{Tc}=\mathrm{ktc} \times \mathrm{R} \times \mathrm{K} \times\left(\mathrm{LS}_{2 \mathrm{D}}-4.12 \times \mathrm{Sg}^{0.8}\right)$

Where ktc is the runoff transport capacity coefficient, $\mathrm{Sg}$ the local slope and R, $\mathrm{K}$ and $\mathrm{LS}_{2 \mathrm{D}}$ are RUSLE parameters. The ktc value is a scaling factor to determine the runoff transport capacity, and this capacity depends on multiple factors such as land use and grid cell size. WaTEM/SEDEM model allows the definition of a ktc value for non-erodible land surfaces (forests and grasslands) as well as one value for erodible land surfaces (crop land) (Van Rompaey et al. 2001; Verstraeten et al. 2002). Long-term measurements of SS load in the catchment under study are scarce, thereby limiting the ability to perform a reliable and accurate calibration of the ktc parameters. To overcome this constraint, a pre-established calibration of the ktc performed by Verstraeten (2006) for seven large river catchments in Belgium was used. Verstraeten (2006) found optimal ktc values of $8 \mathrm{~m}$ for non-erodible land surfaces and $27 \mathrm{~m}$ for erodible land surfaces. Although this calibration was performed in another region than the catchment under study, the same input data, i.e. a SRTM-DEM, resampled to a resolution of $100 \mathrm{~m}$ and a parcel map derived from CORINE Project land cover (EEA 2012) were used. The use of the same input data by Verstraeten (2006) allows us to use the pre-established calibration of the ktc in the present study. Although soil conditions differ between Belgium and the catchment under study, the use of the same input data as Verstraeten (2006) minimises the uncertainty that is caused by using a pre-established calibration of the transport capacity. The use of a pre-established calibration of ktc values results in an uncertainty that cannot be avoided due to the absence of long-term SS data. Therefore, the uncertainty of the set of ktc values on the model results was assessed by performing a sensitivity analysis. The ktc values for non-erodible surfaces were varied from 4 to 12 in increments of 1 . The respective ktc values for erodible surfaces were calculated by multiplying each ktc value for non-erodible land surfaces by a factor of 3.38. This factor is the ratio of the optimal ktc values for erodible to non-erodible surfaces as found by Verstraeten (2006). This means that regardless of grid cell size, a grid cell under forest can transport 3.38 times less SS than a grid cell under agriculture Verstraeten (2006). Further details about the model, input data and parameters, land cover and data sources can be found in the Electronic supplementary material (Section S2).

\subsubsection{WaTEM/SEDEM model validation}

The observed SS load (Horowitz 2003) was calculated based on measurements of in situ concentrations of SS $\left(\mathrm{C}_{\mathrm{SS}}\right)$ and discharge $(\mathrm{Q})$ from the Almourol gauge station (SNIRH 2015), located at the outlet of the watershed of the Tagus river. Monthly measurement data of $\mathrm{C}_{\mathrm{SS}}$ were available for a period of 5 years, from January 1985 until December 1989. Total SS load was calculated as shown in Eq. 2.

$$
\begin{aligned}
\text { observed SS load }\left(\mathrm{t} \cdot \mathrm{month}^{-1}\right)=\mathrm{C}_{\mathrm{SS}}\left(\mathrm{kg} \cdot \mathrm{m}^{-3}\right) & \times \mathrm{Q}\left(\mathrm{m}^{3} \cdot \mathrm{month}^{-1}\right) \\
& \times 0.001\left(\mathrm{t} \cdot \mathrm{kg}^{-1}\right)
\end{aligned}
$$

The observed annual SS load was calculated by summing the observed monthly SS loads for every year. The observed 
annual average of SS load for the entire period 1985-1989 (585278 t.yr ${ }^{-1}$ ) was $20 \%$ lower than the predicted annual SS load that leaves the entire watershed through the river network (727692 t.yr ${ }^{-1}$, as shown in Fig. 2). The overprediction of the annual SS load can be explained by the model simplifications related to land cover (further details in Section 3.6). Another reason for the overprediction of SS lies in the fact that WaTEM/SEDEM does not model internal river dynamics and assumes that all the SS that reach the river channel are transported to the catchment outlet, i.e. SS delivery to the river corresponds to the SS load. SS that are deposited on the river bed are thus not taken into account by the model. Despite the model simplifications assumed, the results show that the model represents the general catchment dynamics and is capable of calculating SS loads in the order of magnitude of the measurements.

\subsubsection{SS delivery from E. globulus stands}

After the optimal input parameters for the model were selected, the SS delivery from the four E. globulus stands towards the Tagus river was modelled. This was done using an adapted version of the WaTEM/SEDEM model that was able to track SS from the upland source area to the main river channel (Notebaart et al. 2005). Spatial data layers delimiting the boundaries of the E. globulus stands were used to define the source areas of SS.

The SS delivered to the Tagus river during one revolution of E. globulus depends on site-specific soil characteristics, rainfall erosivity and on what happens to both the up- and downstream pathways of the stands, which is modelled using the flux-decomposition algorithm (Desmet and Govers 1996b) of WaTEM/SEDEM. The average crop management parameter (Pimenta 1998) (C parameter in RUSLE; further details in Electronic supplementary material, Section S2) is constant for all E. globulus stands with a value of 0.2 , while the average value of soil erodibility (Panagos et al. 2014) (K parameter in RUSLE equation; further details in Electronic

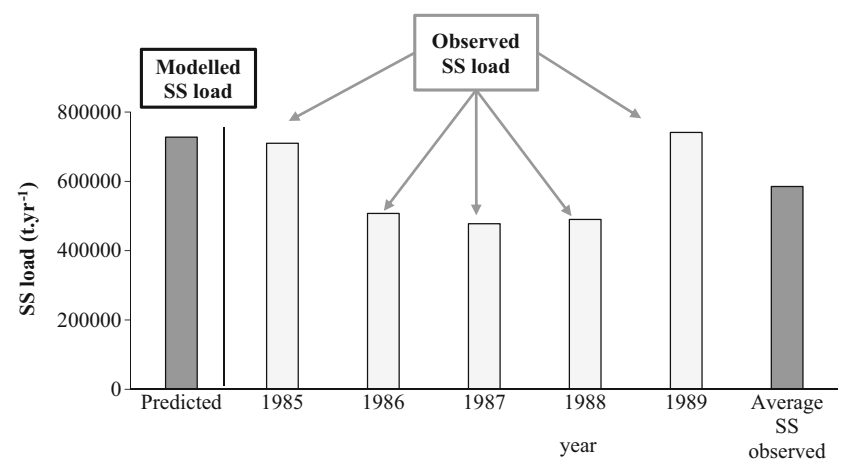

Fig. 2 Results of predicted annual SS load and observed SS load originating from the watershed of the Tagus river during the 5-year period of on-field measuring (1985-1989) supplementary material, Section S2) ranged from 0.028 t.ha.h.ha ${ }^{-1} \cdot \mathrm{MJ}^{-1} \cdot \mathrm{mm}^{-1}$ in stand 1 to 0.048 t.ha.h.ha ${ }^{-1} \cdot \mathrm{MJ}^{-1} \cdot \mathrm{mm}^{-1}$ in stand 4 , and slope-length (LS) ranged from 1.34 (dimensionless) in stand 1 to 16.27 (dimensionless) in stand 3.

Tillage erosion, i.e. the net downslope movement of soil by tillage operations increasing the exposure of less productive sub-soils, is particularly important in hilly areas used for intensive agriculture and forestry (Lindstrom et al. 1992; Govers et al. 1994; Van Oost et al. 2000). E. globulus stands are prone to tillage erosion, mainly due to site preparation and tillage management activities in young stands (Croke 2004; Kosmas et al. 2012). Management activities lead to bare soil surfaces during the first 2 or 3 years of the first rotation, making soils under E. globulus particularly sensitive to soil erosion during this period. Unlike water erosion, soil displacement by tillage in the WaTEM/SEDEM model will only occur within a field, i.e. SS are not transported towards the drainage network (Van Oost et al. 2000). Therefore, the contribution of tillage erosion to the total SS that reach the drainage network was not taken into account.

During the first part of each rotation cycle, the canopy is not completely closed until approximately the age of 5 years (Quinteiro et al. 2015b). During this period, the soil is less protected from raindrop impact and therefore more prone to erosion by water. After canopy closure, the soil is more protected from water erosion. This situation is taken into account in the average crop management parameter of E. globulus of the RUSLE used by the WaTEM/SEDEM model. The average $\mathrm{C}$ value of 0.2 means that topsoil erosion will be reduced to $20 \%$ compared to the amount that would have been eroded under continuous fallow conditions.

\subsection{Forest management inventory}

Inventory data for the ecosystem impact categories of the ReCiPe method (Goedkoop et al. 2013) associated with the forest management operations were collected. These are representative of a high intensity management model, characterised by adoption of the best management practices recommended for E. globulus stands, as described in Dias et al. (2007) and Dias and Arroja (2012). All forest management operations undertaken during the stages of site preparation, stand establishment, stand tending, felling and infrastructure establishment were taken into account.

The amount of carbon dioxide $\left(\mathrm{CO}_{2}\right)$ assimilated during E. globulus growth was not taken into account. It was assumed that this amount is equal to the amount of $\mathrm{CO}_{2}$ that will be released back to the atmosphere due to wood oxidation along the downstream life cycle stages of wood (Dias and Arroja 2012), i.e. biogenic carbon that is emitted during the use and end-of-life stages of paper or other forest-derived products. The production of fuels, lubricants and fertilisers 
required for management operations was considered (Dias et al. 2007; Dias and Arroja 2012). Transport of workers, machinery and materials (fuels, lubricants and fertilisers), as well as capital goods, were excluded as they did not contribute significantly to the overall result and the associated distances and means of transportation greatly vary within the country.

For the operations carried out during site preparation (stand tending and infrastructure establishment), the inputs of fuels, lubricants and fertilisers were directly obtained per unit of land area (Dias et al. 2007). For felling, the inputs of fuels and lubricants were first obtained per unit of wood volume under bark and then were expressed per unit of land area by considering the average wood productivity (average annual increment) of each stand $\left(8.5 \mathrm{~m}^{3} \cdot \mathrm{ha}^{-1}\right.$ for stands 1 and 2 , and $7.4 \mathrm{~m}^{3} \cdot \mathrm{ha}^{-1}$ for stands 2 and 3 ) and the density of wood $\left(550 \mathrm{~kg}\right.$ dry matter. $\left.\mathrm{m}^{-3}\right)$. A detailed list of the inputs related to forest management operations can be found in the Electronic supplementary material (Section S3).

\subsection{Impact assessment of SS and sensitivity analysis of model input parameters}

The performed quantitative impact assessment of SS on the potential disappearance of macroinvertebrates, algae and macrophytes in the Tagus river follows the SS environmental impact pathway illustrated by the shaded boxes of Fig. 1 . As mentioned in the 'Introduction' section, high concentrations of SS can physically affect macroinvertebrates, algae and macrophytes. The gills and small appendages or filter feeding structures of macroinvertebrates can be clogged. Both algae and macrophytes require light penetration throughout the water column for photosynthesis purposes. The increase of the turbidity of the water column due to SS reduces light availability, which reduces the photosynthesis rates, leading to lethal effects on these primary producers. Based on a fate and effect model, Quinteiro et al. (2015a) derived spatially explicit endpoint characterisation factors (CFs) (expressed in potentially disappeared fraction (PDF). $\mathrm{m}^{3}$. day. $\mathrm{mg}_{\mathrm{SS}}^{-1}$ ) for different river sections, including the ones for the Tagus river Almourol and Vila Velha de Rodão river sections. Based on the drainage network (Electronic Supplementary Material, Fig. S1), it can be seen that stands 1 and 2 deliver SS to the Almourol river section, while stands 3 and 4 deliver SS to the Vila Velha de Rodão river section. The Almourol river section has a slightly higher average water volume and average flow than the Vila Velha de Rodão section (Quinteiro et al. 2015a).

The fate factors represent the marginal increase in the concentration of SS due to a marginal increase of the emission rate of $\mathrm{SS}$ in river sections (Quinteiro et al. 2015a). These factors consider the exposure to the SS, reflecting the environmental residence time of SS in river sections, which depends strongly on the river section flow rate.

Figure 1 clarifies the defined inventory/impact assessment boundaries, which are consistent with those proposed by Quinteiro et al. (2015a) for the SS impact pathway on ecosystem quality. However, it should be noted that the first brace of Fig. 1 in Quinteiro et al. (2015a) erroneously includes the SS delivered to rivers in the fate factors. This is now corrected in the erratum to Quinteiro et al. (2015a). Transport has been included in the inventory phase and not in the impact assessment (fate factor), as suggested by ISO 14044 (2006b), which refers that 'the fate and transport of the substances should be part of the characterisation model'. In this study, the inventory is related not only to topsoil erosion but also to the amount of SS that are transported throughout the landscape until they reach a surface water system (compartments of the surrounding environment), as described in Quinteiro et al. (2014, 2015a). This modelling choice follows the PestLCI model developed by Dijkman et al. (2012), which estimates pesticide emissions to air, surface water and groundwater for use in inventory modelling of field applications, and was selected to enable the framework and method to be implemented for a large range of river sections.

Although the inventory for the impact of erosion on soil properties is usually expressed as mass of eroded soil, in the case of the impact of erosion on aquatic ecosystems addressed in this study, the inventory is expressed as mass of SS because the inventory modelling is different in the two cases. For impacts on soil properties (such as loss of productivity or soil depletion) matter the quantity of soil eroded from the field under study, being not relevant the identification of the surrounding environment for which eroded soil is transferred and in what quantity. On its turn, for the impact of erosion on aquatic ecosystems is crucial to consider the amount of displaced SS from a specific land use production system that is transported throughout the landscape towards a surface water system. Depending on the digital elevation model, transport capacity coefficients, soil erodibility, rainfall erosivity, slope-length and land use types of downstream areas, the quantity of SS that are deposited throughout downstream fields until reaching the drainage network can vary significantly. This means that the quantity of SS delivered to the water column can be significantly different from the quantity of eroded soil. The LCA practitioner should be aware that although the anthropic intervention is the same, the inventory modelling is more complex in the case of the impacts on aquatic ecosystems, requiring geographic information system (GIS) data. By these reasons, the ISO 14044 recommendation about including the transport in the impact assessment was not followed 
and, instead, the transport of SS towards the water column was considered as part of the inventory.

The effect factors reflect the PDF of macroinvertebrates, algae and macrophytes due to a change in the detrimental concentrations of SS in river sections (Quinteiro et al. 2015a). These factors were developed based on a concentration-response relationship between the detrimental concentration of SS in the water column and the sub-lethal and lethal physical effects on macroinvertebrates, algae and macrophytes in river sections.

For macroinvertebrates, $\mathrm{CF}$ is higher for the Tagus-Vila Velha de Rodão river section $\left(2.4 \times 10^{-6} \mathrm{PDF} . \mathrm{m}^{3}\right.$. day. $\left.\mathrm{mg}_{\mathrm{Ss}}{ }^{-1}\right)$ than for the Tagus-Almourol river section $\left(1.4 \times 10^{-6}\right.$ PDF. $\mathrm{m}^{3}$. day. $\mathrm{mg}_{\mathrm{SS}}^{-1}$ ). In contrast, for algae and macrophytes, the CF for the Tagus-Almourol river section $\left(4.6 \times 10^{-7} \times\right.$ PDF. $\mathrm{m}^{3}$. day. $\left.\mathrm{mg}_{\mathrm{SS}}^{-1}\right)$ is slightly higher than the one developed for the Tagus-Vila Velha de Rodão $\left(4.2 \times 10^{-7}\right.$ PDF. $\mathrm{m}^{3}$. day. $\left.\mathrm{mg}_{\mathrm{SS}}^{-1}\right)$.

The spatial SS inventory contains some assumptions and simplifications (further details in the Electronic supplementary material, Section S4) and the calculation of eroded SS strongly depends on the parameter values of the RUSLE. Therefore, a sensitivity analysis was performed in which the values for the crop factor $(\mathrm{C})$, soil erodibility $(\mathrm{K})$ and rainfall erosivity $(\mathrm{R})$ parameters were varied in a range of $\pm 10 \%$.

To demonstrate how the SS characterisation model developed by Quinteiro et al. $(2014,2015 \mathrm{a})$ can help to improve the environmental assessment in forestry, the results were compared with the commonly used endpoint ecosystem impact categories from the ReCiPe method (Goedkoop et al. 2013), namely freshwater eutrophication, freshwater ecotoxicity, terrestrial ecotoxicity, terrestrial acidification and climate change. Damage to macroinvertebrates, algae and macrophytes in the model developed by Quinteiro et al. (2015a) is expressed in different units (PDF. $\mathrm{m}^{3}$.day. $\mathrm{mg}^{-1}$ ) than those used to express ecosystem damage estimated in the ReCiPe method (species.yr.mg ${ }^{-1}$ ). Therefore, to ensure comparability, SS CFs in PDF. $\mathrm{m}^{3}$. day. $\mathrm{mg}_{\mathrm{SS}}^{-1}$ were converted to units of species. $\mathrm{yr}_{\mathrm{r}} \mathrm{mg}_{\mathrm{SS}}^{-1}$, considering the total macroinvertebrates, algae and macrophytes species density. Total species density was determined by counting the total number of least concerned, near threatened, vulnerable, endangered and critically endangered macroinvertebrates species (11,777 species) and algae and macrophytes species $(20,837$ species $)$ in freshwater systems listed by the International Union for Conservation of Nature (IUCN 2015) and the total volume of freshwater present in the earth rivers, streams and lakes $\left(126,700 \mathrm{~km}^{3}\right)$ (Goedkoop et al. 2013). However, the use of a global average value of macroinvertebrates, algae and macrophytes for addressing the total species richness in the Tagus river sections creates a source of uncertainty for site-specific SS impact results. This issue is discussed in 'Implications and recommendations' section.

\section{Results and discussion}

\subsection{SS inventory}

As mentioned in the 'Suspended solids inventory' section, the transport of eroded soil in the WaTEM/SEDEM model has to be constrained by selecting adequate ktc values. Since longterm measurements of $\mathrm{C}_{\mathrm{SS}}$ in the catchment under study are scarce and there is limited ability to develop locally calibrated ktc values, a pre-established calibration of the transport capacity coefficients by Verstraeten (2006) was used. The lack of data also justifies the use of the WaTEM/SEDEM model, which has a limited amount of necessary input data but still captures major SS dynamics in large catchments (Schindler and Hilborn 2015). This is a common challenge in LCA in which there is an increasing trend toward the use of regionalised impact assessment models, but the availability of relevant data to define local parameters is often scarce. The use of a pre-established calibration of ktc values results in uncertainty that cannot be avoided due to absence of longterm monitoring SS data. Therefore, the uncertainty is analysed by means of a sensitivity analysis. The Electronic supplementary material (Section S2) provides the description and the results of the sensitivity analysis performed. WaTEM/ SEDEM predictions of SS are indeed sensitive to the ktc values used and vary between $-55 \%$ and $+23 \%$ of the measured SS load for the parameter value range considered (further details in Electronic Supplementary Material, Fig. S7). Differences ranging from -7 to $-55 \%$ (considering ktc values lower than the default values) indicate that the predicted SS delivered to river are lower than the SS delivery estimated with the default ktc values. In contrast, differences ranging from +6 to $+23 \%$ (considering ktc values higher than the default values) indicate that the predicted SS are higher than the SS load estimated with the default ktc values. Lower ktc values than the default ones result in less reliable model predictions, as the long-term predicted SS load was increasingly lower than the yearly SS observed load. Higher ktc values than the default ones increase the overestimation of the SS load compared to the observed yearly average SS load observed.

A higher K parameter leads to a higher susceptibility to soil detachment, and consequently to a higher SS delivery. Nonetheless, the productivity should also be considered. For instance, stand 4 was characterised by the highest susceptibility to soil detachment as it has the highest average $\mathrm{K}$ parameter (0.041 t.ha.h.ha ${ }^{-1} \cdot \mathrm{MJ}^{-1} \cdot \mathrm{mm}^{-1}$ ) and was responsible for the highest total SS load delivered to the Tagus river, in particular to the Vila Velha de Rodão river section $(13,556.2$ t.revolu$\left.\operatorname{tion}^{-1}\right)$. However, this stand also has the highest productive area (103 ha), which means that per FU, the SS are 131.6 tha $^{-1}$.revolution ${ }^{-1}$, being lower than the SS for stands 2 and 3 (Table 1). Stand 1 has the lowest SS delivery, in 
Fig. 3 Potential damage on aquatic biota due to the increased SS load in the water column from the E. globulus stands studied

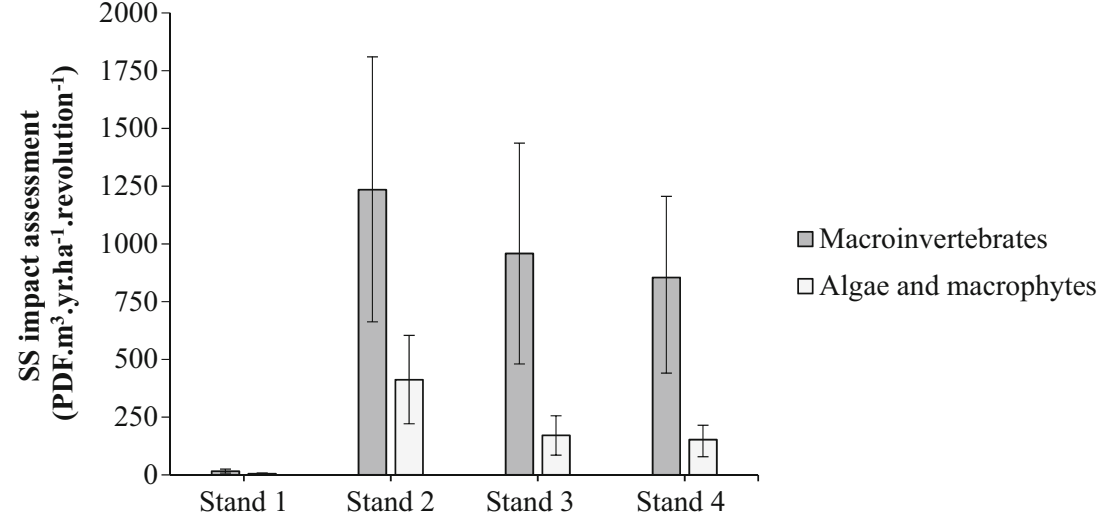

particular to the Almourol river section, as this stand has the lowest average $\mathrm{K}$ values and productive area and is located in a relatively flat area, therefore having the lowest average $\mathrm{LS}_{2 \mathrm{D}}$ value.

\subsection{SS impact assessment}

As shown in Table 1, the E. globulus stands under study deliver SS to two different sections of the Tagus river (Vila Velha de Rodão and Almourol), for which spatial SS CFs are available (Quinteiro et al. 2015a). By linking the SS inventory with spatial CFs of these river sections, the potential damage on macroinvertebrates, algae and macrophytes due to the increased SS in the water column can be assessed. As can be seen in Fig. 3, the resulting SS impacts ranged from 15.5 to 1234.9 PDF. $\mathrm{m}^{3}$.yr.ha ${ }^{-1}$.revolution ${ }^{-1}$ for macroinvertebrates and from 5.2 to 411.9 PDF. $\mathrm{m}^{3}$.yr.ha ${ }^{-1}$.revolution ${ }^{-1}$ for algae and macrophytes. The potential impacts for macroinvertebrates are higher compared to those for algae and macrophytes because high $\mathrm{C}_{\mathrm{SS}}$ clog the feeding structures and damage the gills and digestive structures of macroinvertebrates, making these organisms more sensitive to SS than algae and macrophytes Quinteiro et al. (2015a). The SS potential impacts are higher than one because, since the results are expressed per hectare and per revolution, the values become quite large. In actual fact, the impacts are spread over a much large volume of water than $1 \mathrm{~m}^{3}$ and over a much longer time period than 1 year (PDF. $\mathrm{m}^{3}$.yr.ha ${ }^{-1}$.revolution ${ }^{-1}$ ).

Although the SS CF for macroinvertebrates is higher for the Tagus-Vila Velha de Rodão river section, the highest impact on macroinvertebrates biodiversity was observed for the Tagus-Almourol river section. This is because of the higher SS production by stand 2, which produces a SS load per FU which is $40 \%$ higher than inventoried for stands 3 and 4 (Tagus-Vila Velha de Rodão river section). This high SS delivery from stand 2 per FU in combination with the higher SS CF for algae and macrophytes in the Tagus-Almourol river section results in the highest damage on algae and macrophyte biodiversity. Stand 1 contributes to a significantly less damage on aquatic species than the other stands under analysis because, as it is located in a flat area, it delivers the lowest amount of SS per FU to the Tagus river (4.1 t.ha ${ }^{-1}$.revolution ${ }^{-1}$ ).

Given the significance of the ktc parameter (discussed in the 'S S inventory 3.1' section), Fig. 3 also shows the uncertainty associated with the variability of this parameter using the absolute deviation as the measure of dispersion. The error bars show the deviation of the SS impacts results from the SS impacts results obtained using the default ktc values ( 8 and $27 \mathrm{~m}$ ), strengthening the relevance of the ktc calibration for different environments.

\subsection{Sensitivity analysis}

A sensitivity analysis was carried out to evaluate the influence of input data of the RUSLE on the potential impacts on macroinvertebrates, algae and macrophytes. Changes of $\pm 10 \%$ in the default input $\mathrm{C}, \mathrm{K}$ and $\mathrm{R}$ parameters were considered. Significant changes in the SS potential impacts were obtained when the $\mathrm{C}$ parameter was changed by $-10 \%$. Potential impacts increased by $10 \%$ for stand 1 , and decreased between 24 (stand 2) and $49 \%$ (stand 4) compared to the potential impact of the reference case (Table 2). It should be kept in mind that soil erosion from the E. globulus stands depends on erosion dynamics upslope of these areas. For example, when a lower $\mathrm{C}$ parameter is assigned to the entire watershed, the runoff that reaches a stand might not be saturated with SS. In this case, more soil can be eroded from that stand, resulting in a higher SS load delivered to river networking. On the other hand, the $\mathrm{SS}$ delivery to the river can also decrease when a lower $\mathrm{C}$ parameter is chosen because less erosion can occur in the stands. Besides, as the ktc parameter is proportional to the $\mathrm{C}$ parameter, runoff can transport smaller amounts of SS from the E. globulus stands. When a higher C parameter is chosen, it is possible that all runoff that reaches the stand is SS- 
saturated (the transport capacity of SS that can pass through one pixel is reached). It is thus clear that the effect of different parameter values on the amount of eroded soil from the stands is also dependent on the area up- and downstream of the stands.

When the $\mathrm{C}$ parameter is increased by $10 \%$, minor or even no increase in SS potential impacts for aquatic biota were determined, which indicates that runoff that reaches E. globulus stands is SS-saturated. In contrast to the C parameter, changes in the $\mathrm{K}$ and $\mathrm{R}$ parameters have a significantly lower influence on the SS potential impacts on macroinvertebrates, algae and macrophytes (up to $\pm 11 \%$ ) for all stands under analysis (Table 2). This indicates that the uncertainties of the $\mathrm{K}$ and $\mathrm{R}$ factors that were used for the simulations are limited. The $\mathrm{C}$-factor, on the other hand, did affect model results significantly. Because a C-factor of 0.2 for E. Globulus was determined in Pimenta (1998), it was chosen to perform the simulation using this value. It should however be kept in mind that model uncertainty arises from the different parameters used.

\subsection{Impact assessment of forest management operations in E. globulus stands}

The impact assessment of E. globulus forest management operations was performed using the endpoint characterisation factors recommended by ReCiPe method (Goedkoop et al. 2013). Table 3 shows the impact assessment results due to the occupation of 1 ha by E. globulus during one revolution. Climate change impact accounted for the majority of the total estimated ecosystem impacts, with $3.0 \times 10^{-5}$ species.yr.ha $^{-1}$.revolution ${ }^{-1}$ ( $98 \%$ of the total ecosystem impacts). The largest contribution to climate change comes from $\mathrm{CO}_{2}(65 \%)$, which is emitted mainly during E. globulus forest operations due to fossil fuel combustion (Electronic Supplementary Material, Table S2). Dinitrogen monoxide $\left(\mathrm{N}_{2} \mathrm{O}\right)$ emissions resulting from fertiliser application were responsible for $35 \%$ of predicted climate change impacts. In contrast, freshwater eutrophication was responsible for the lowest impact, representing $0.01 \%$ of the total E. globulus forest management environmental impacts, mainly due to phosphorous $(\mathrm{P})$ and phosphate $\left(\mathrm{PO}_{4}^{3-}\right)$ emissions associated with application of P-containing fertilisers during stand tending (Electronic Supplementary Material, Table S2). The emission of some pollutants to air and soil, such as cadmium (soil and air emissions), chromium and polycyclic aromatic hydrocarbons (air emissions) during tillage operations and carbofuran (soil emissions) and bromine (air, soil and water emissions) emitted during fertiliser production, are the main contributors to freshwater and terrestrial ecotoxicity impacts (Table 3). Terrestrial acidification impacts come mainly from stand tending operations, in particular ammonia $\left(\mathrm{NH}_{3}\right)$ 
Table 3 Impact assessment results associated with occupation of 1 ha by E. globulus during one revolution (36 years)

\begin{tabular}{|c|c|c|c|c|c|c|c|}
\hline & \multicolumn{7}{|c|}{ species.yr.ha ${ }^{-1} \cdot$ revolution $^{-1}$} \\
\hline & $\begin{array}{l}\text { SS potential impacts } \\
\text { on macroinvertebrates }\end{array}$ & $\begin{array}{l}\text { SS potential impacts on } \\
\text { algae and macrophytes }\end{array}$ & $\begin{array}{l}\text { Freshwater } \\
\text { eutrophication }\end{array}$ & $\begin{array}{l}\text { Freshwater } \\
\text { ecotoxicity }\end{array}$ & $\begin{array}{l}\text { Terrestrial } \\
\text { ecotoxicity }\end{array}$ & $\begin{array}{l}\text { Terrestrial } \\
\text { acidification }\end{array}$ & $\begin{array}{l}\text { Ecosystem } \\
\text { climate change }\end{array}$ \\
\hline Stand 1 & $1.4 \times 10^{-9}$ & $8.5 \times 10^{-10}$ & $3.6 \times 10^{-9}$ & $1.3 \times 10^{-7}$ & $2.3 \times 10^{-8}$ & $5.4 \times 10^{-7}$ & $3.0 \times 10^{-5}$ \\
\hline Stand 2 & $1.1 \times 10^{-7}$ & $6.8 \times 10^{-8}$ & $3.6 \times 10^{-9}$ & $1.3 \times 10^{-7}$ & $2.3 \times 10^{-8}$ & $5.4 \times 10^{-7}$ & $3.0 \times 10^{-5}$ \\
\hline Stand 3 & $8.9 \times 10^{-8}$ & $2.8 \times 10^{-8}$ & $3.6 \times 10^{-9}$ & $1.3 \times 10^{-7}$ & $2.3 \times 10^{-8}$ & $5.4 \times 10^{-7}$ & $3.0 \times 10^{-5}$ \\
\hline Stand 4 & $7.9 \times 10^{-8}$ & $2.5 \times 10^{-8}$ & $3.6 \times 10^{-9}$ & $1.3 \times 10^{-7}$ & $2.3 \times 10^{-8}$ & $5.4 \times 10^{-7}$ & $3.0 \times 10^{-5}$ \\
\hline
\end{tabular}

emission due to fertilisation (Electronic Supplementary Material, Table S2).

\subsection{Comparison of impacts from SS and forest management}

SS potential impacts and forest management impacts resulting from the occupation of 1 ha by E. globulus during one revolution are presented in Table 3. The results show that for macroinvertebrates, the SS impacts range from $1.4 \times 10^{-9}$ species.yr.ha ${ }^{-1} \cdot$ revolution $^{-1}$ (stand 1) to $1.1 \times 10^{-7}$ species.yr.ha ${ }^{-1}$.revolution ${ }^{-1}$ (stand 2), while for algae and macrophytes the SS impacts range from $8.5 \times 10^{-10}$ species.yr.ha $^{-1}$.revolution ${ }^{-1}$ (stand 1$)$ to $6.8 \times$ $10^{-8}$ species.yr.ha ${ }^{-1}$.revolution ${ }^{-1}$ (stand 2). For some stands, SS potential impacts on macroinvertebrates have the same order of magnitude than freshwater eutrophication, freshwater ecotoxicity, terrestrial ecotoxicity and terrestrial acidification impacts (Table 3). For algae and macrophytes, all stands with exception of stand 1 present SS impacts of the same order of magnitude as terrestrial ecotoxicity, one order of magnitude higher than freshwater eutrophication and two orders of magnitude lower than freshwater ecotoxicity and terrestrial acidification. For stand 1, the SS potential impacts on algae and macrophytes are at least one order of magnitude lower than all other impacts resulting from E. globulus production. For all stands under study, ecosystem climate change presents a significantly higher impact compared to SS impacts on macroinvertebrates, algae and macrophytes.

In some stands, SS potential impacts have a higher relevance than other commonly established impact categories, with the exception of ecosystem climate change. These results highlight that the newly developed framework and method (Quinteiro et al. 2014, 2015a) to determine the spatial SS potential impacts on aquatic biota is a significant contribution to a more comprehensive local environmental assessment of forest and agricultural systems. Extensive deforestation for cropland and pasture and intensive agriculture have dramatically accelerated soil erosion, leading to a gradually thinner soil and a loss of productivity (Montgomery 2007; Pimentel and Burgess 2013). Land areas covered by forest are more resistant to water erosion than croplands because tree canopies have the effect of decreasing the effective rainfall erosive force (FAO 2013). However, it should be noted that for the five endpoint ecosystem impact categories, the non-spatially explicit CFs were derived from the ReCiPe method, which could skew the comparison between these impact categories and the SS impacts, which uses spatially explicit CFs. In order to improve spatially explicit environmental impact assessments, Struijs et al. (2010) determined spatially differentiated CFs for $\mathrm{P}$ emission due to fertiliser applications. These authors provide a CF for the Tagus river equivalent to $6.5 \times 10^{-15}$ species. yr. $\mathrm{mg}_{\mathrm{SS}}^{-1}$ (following the recommendation of the $\mathrm{ReCiPe}$ method to convert units of PDF. $\mathrm{m}^{3}$. day. $\mathrm{m}_{\mathrm{SS}}^{-1}$ to species.yr.mg $\mathrm{SS}_{\mathrm{SS}}^{-1}$, considering the freshwater species density of $7.9 \times 10^{-10}$ species.yr. $\mathrm{kg}^{-1}$ ), which is lower than the generic $\mathrm{CF}$ for $\mathrm{P}$ emission due to fertiliser application available in ReCiPe method $\left(2.4 \times 10^{-12}\right.$ species. yr. $\left.\mathrm{mgss}_{\mathrm{SS}}^{-1}\right)$. Consequently, a CF for the Tagus river of $6.5 \times 10^{-15}$ species. yr. $\mathrm{mg}_{\mathrm{SS}}^{-1}$ leads to lower freshwater eutrophication impacts $\left(7.1 \times 10^{-12}\right.$ species.yr.ha ${ }^{-1}$.revolution $\left.{ }^{-1}\right)$ compared to the results obtained with the generic CF available in ReCiPe method $\left(2.6 \times 10^{-9}\right.$ species.yr.ha $^{-1}$.revolution $\left.{ }^{-1}\right)$. This indicates that ecosystem freshwater species are less vulnerable to $\mathrm{P}$ emissions in the Tagus river compared to the average results for European continental waters.

\subsection{Implications and recommendations}

There are some aspects that should be a priority in further research: (1) improvement of SS modelling, in particular the calibration of the transport capacity coefficient and the identification of SS-trapping sites and forest roads, (2) CFs at an adequate spatial resolution related to life cycle inventories, (3) determination of site-specific freshwater species richness and (4) application of framework and method developed for other land uses in other regions with different soil and climatic conditions.

Concerning the first item, to conduct a spatial SS inventory, the WaTEM/SEDEM model requires a calibration of the ktc parameters in order to obtain an optimal relation between 
model parameters and observed erosion dynamics, as discussed in 'Suspended solids inventory' section. Because the transport capacity depends on multiple factors such as climate and landscape structure, a new calibration should be performed when applying the model to a new environment. For this purpose, long-term on-site monitoring of SS load at the catchments outlet is necessary. As this data was not present for the watershed under study, predefined transport capacities that were obtained for the same spatial resolution in another region were used. However, the ktc sensitivity analysis (Electronic supplementary material, S2) showed that the preestablished calibrated ktc values give a better approximation of the SS load on a yearly basis than other ktc values. In addition, in 'WaTEM/SEDEM model validation' section, it is shown that despite the use of pre-established calibrated ktc values and model simplifications, this model is capable of calculating SS loads in the order of magnitude of the measurements.

The general overprediction of the SS delivered to the Tagus river with the WaTEM/SEDEM model may result from the fact that SS-trapping sites, i.e. vegetation barriers (e.g. hedges and grass strips), ponds, reservoirs and dams (in particular the Cedillo, Fratel and Belver dams), were not properly taken into account. For example, it has been observed that a fraction of the overland flow can infiltrate near the field boundary and SS are likely to be deposited here, due to differences in vegetation and soil surface conditions (Meyer et al. 1995; Slattery and Burt 1997; Takken et al. 1999). Although this mechanism is taken into account in the WaTEM/SEDEM model, the input parameters for soil trapping at field borders were determined for the Belgian loam belt and their applicability was not validated for our study area. Although ponds, reservoirs and dams also act as a SS trap, these infrastructures were not considered due to data constraints. In addition, although forest roads contribute disproportionally to runoff and SS production in forested areas (Chappell et al. 1999; La Marche and Lettenmaier 2001; Croke and Hairsine 2006), these were not considered due to data constraints, which can introduce uncertainty on SS inventory. Further research is needed to implement the abovementioned constraints in an operational model structure for the area under study.

Regarding the second item, the spatial potential environmental impacts of SS on aquatic biota depend on (1) the quantity of SS production, i.e. the amount of soil eroded from the land use production systems, (2) the properties of the these SS and on (3) the characteristics of land use production systems (e.g. soil, rainfall and geomorphological characteristics). In the assessment of these impacts and others, affecting local, regional and continental scales, adequate spatial information is required in order to accurately establish accordance between the inventory and the impact assessment phase (Reap et al. 2008). The quality of LCA studies can be compromised if the LCA practitioner has difficulties to establish a connection between $\mathrm{CFs}$ with high spatial resolution and the related spatial inventory or vice versa. It is also not easy to obtain information about background processes (e.g. fertiliser, diesel, petrol and lubricating oil production processes in this case study), hampering the development of endpoint site-specific CFs for these processes. Indeed, finding an optimal spatial resolution to construct life cycle inventories remains a major scientific challenge in LCA (Huijbregts 2013).

Regarding the third item (species richness), it is important to keep in mind that determining this factor for specific river sections is complex. Adequate information on the number of macroinvertebrates, algae and macrophytes species in the river sections under study was not available. The use of a global average value of macroinvertebrate, algae and macrophyte density for site-specific SS impacts (in units of species.yr.ha ${ }^{-1}$.revolution ${ }^{-1}$ ) creates a source of uncertainty since local species richness can vary depending on the characteristics of the river sections under study. Further improvements in the characterisation of freshwater species richness should be considered in order to increase the robustness of the comparison between impact categories.

Finally, in order to further increase the applicability of the framework and method developed to a global scale, the SS potential impacts should also be assessed for other land use production systems (e.g. forest, grassland, pastures, permanent and annual crops, shrubland, urban), thereby enhancing the knowledge on the impact of SS on aquatic biota in comparison with other impact categories. Spatially explicit SS inventory is a time- and resource-consuming procedure. However, the developed framework by Quinteiro et al. (2014) can be applied to a wide range of foreground processes. Once several case studies are conducted, the studied foreground processes can be used as background processes for other studies. By this way, datasets would be available to be integrated into inventory databases. Another topic of future research should be the development of global generic CFs for SS impacts from different land use systems.

\section{Conclusions}

This study shows the applicability of the framework and method proposed by Quinteiro et al. (2014, 2015a) by assessing the potential damages of SS on ecosystems for macroinvertebrates, algae and macrophytes. Soil erosion by water has been characterised as one of the most upsetting problems in rivers. The SS impact results allow the conclusion that the increase of SS in the water column can cause biodiversity damage and that the calculated impacts can have a similar or even higher contribution to the total environmental impact than the commonly established endpoint impact categories of the ReCiPe method (such as freshwater eutrophication, freshwater ecotoxicity, terrestrial ecotoxicity and terrestrial 
acidification). This study shows that SS impacts on aquatic organisms can vary substantially when using a detailed regionalisation level such as the local resolution scale. The SS impacts are highly dependent on the geographical location of the land use system, soil properties and land use type itself. A wide application of the framework and method developed at a local scale will enable the establishment of a regionalised SS inventory database and a deep characterisation of the potential environmental impacts of SS on local aquatic environments. Although being time-consuming steps, requiring the collection of specific data on the land use system, soil properties and raster layers with identical spatial resolution and coverage, once this research is done, the performing of a regionalised comprehensive assessment of SS impacts for different land use systems at a catchment level would highlight the gravity of the SS problems for the local aquatic ecosystem. This shows that addressing of topsoil erosion impacts in LCA is needed, helping in the establishment of mitigation measures to avoid or reduce the SS environmental impacts on the aquatic biota and preserving the aquatic ecosystem services. Furthermore, further research should focus on including the SS impacts for fishes, addressing both the potential damage on human health and aquatic ecosystems.

Acknowledgments We thank FCT (Science and Technology Foundation - Portugal) and POHP/FSE funding program for the scholarship granted to Paula Quinteiro (SFRH/BD/78690/2011).

\section{References}

Allan JD, Castillo MM (2007) Stream ecology. Structure and function of running waters. Springer, The Netherlands

Angermeier PL, Wheeler AP, Rosenberger AE (2004) A conceptual framework for assessing impacts of roads on aquatic biota. Fisheries 29:19-29

Beck T, Bos U, Wittstock B, Baitz M, Ficher M, Sedlbauer K (2011) Land Use Indicator Value Calculation in Life Cycle Assessment (LANCA) - Method Report. Fraunhofer IBP, Stuttgart

Bilotta GS, Brazier RE (2008) Understanding the influence of suspended solids on water quality and aquatic biota. Water Res 42:2849-2861

Brandão M, Milà i Canals L (2013) Global characterisation factors to assess land use impacts on biotic production. Int $\mathrm{J}$ Life Cycle Assess 18:1243-1252

Chappell NA, McKenna P, Bidin K, Douglas I, Walsh RP (1999) Parsimonious modelling of water and suspended sediment flux from nested catchments affected by selective tropical forestry. Philos Trans R Soc Lond B Biol Sci 354:1831-1846

Collins AL, Naden PS, Sear DA, Jones JI, Foster IDL, Morrow K (2011) Sediment targets for informing river catchment management: international experience and prospects. Hydrol Process 25:2112-2129

Commision E (2005) Soil atlas of Europe. European Soils Bureau Network. European Commission, Luxembourg

Croke J (2004) Forests and soil erosion control. In: Burley J, Evans J, Youngquist J (eds) Encyclopaedia of forest sciences. Elsevier, Amsterdam

Croke JC, Hairsine PB (2006) Sediment delivery in managed forests: a review. Environ Rev 14:59-87
Desmet PJJ, Govers G (1995) GIS-based simulation of erosion and deposition patterns in an agricultural landscape: a comparison of model results with soil map information. Catena 25:389-401

Desmet PJJ, Govers G (1996a) A GIS procedure for automatically calculating the USLE LS factor on topographically complex landscape units. J Soil Water Conserv 51:427-433

Desmet PJJ, Govers G (1996b) Comparison of routing algorithms for digital elevation models and their implications for predicting ephemeral gullies. Int J Geogr Inf Syst 10:311-331

Dias AC, Arroja L (2012) Environmental impacts of eucalypt and maritime pine wood production in Portugal. J Clean Prod 37:368-376

Dias AC, Arroja L, Capela I (2007) Carbon dioxide emissions from forest operations in Portuguese eucalypt and maritime pine stands. Scand J For Res 22:422-432

Dijkman TJ, Birkved M, Hauschild MZ (2012) PestLCI 2.0: a second generation model for estimating emissions of pesticides from arable land in LCA. Int J Life Cycle Assess 17:973-986

Diodato N, Bellocchi G (2010) MedREM, a rainfall erosivity model for the Mediterranean region. J Hydrol 387:119-127

EEA (2012) CORINE Land Cover 2006. In: Eur. Environ. Agency. http:// www.eea.europa.eu/data-and-maps/data/corine-land-cover-2006raster-2. Accessed December 2014

FAO (2013) State of Mediterranean Forests 2013. Food and Agriculture Organization of the United Nations

Geyer R, Lindner JP, Stoms DM, Lindner JP, Davis FW, Wittstock B (2010a) Coupling GIS and LCA for biodiversity assessments of land use, Part 1: inventory modeling. Int J Life Cycle Assess 15:692-703

Geyer R, Lindner JP, Stoms DM, Davis FW, Wittstock B (2010b) Coupling GIS and LCA for biodiversity assessments of land use, Part 2: impact assessment. Int J Life Cycle Assess 15:692-703

Goedkoop M, Heijungs R, Huijbregts M, de Schryver A, Struijs J, Van Zelm R (2013) ReCiPe. A Life Cycle Impact Assessment method which comprises harmonised category indicators at the midpoint and the endpoint level. First edition (version 1.08). Ministerie van Volkshuisvesting. Ruimtelijke Ordening en Milieubeheer, The Netherlands

Govers G, Vandaele K, Desmet PJJ, Poesen J, Bunte K (1994) The role of soil tillage in soil redistribution on hillslopes. Eur J Soil Sci 45:469-478

Grimm M, Jones R, Montanarella L (2002) Soil erosion risk in Europe. European Soil Bureau, Institute for Environment \& Sustainability, JRC Ispra, Italy

Horowitz AJ (2003) An evaluation of sediment rating curves for estimating suspended sediment concentrations for subsequent flux calculations. Hydrol Process 17:3387-3409

Huijbregts M (2013) A critical view on scientific consensus building in Life Cycle Impact Assessment. Int J Life Cycle Assess 19:477-479

ICNF (2013) $6^{\circ}$ Inventário florestal nacional. [6th National forest inventory.]. Áreas dos usos do solo e das espécies florestais de Portugal. Resultados preliminares. Instituto da Conservação da Natureza e das Florestas, Lisboa, Portugal

IPCC (2007) Climate change 2007: the physical science basis. Contribution of working group I to the fourth assessment report of the Intergovernmental Panel on Climate Change. Cambridge University Press, New York, USA

ISO (2006a) Environmental management-Life Cycle AssessmentPrinciples and Frameworks. ISO 14044. International Organization for Standardization, Geneva, Switzerland

ISO (2006b) Environmental management-Life Cycle AssessmentRequirements and Guidelines. ISO 14044. International Organization for Standardization, Geneva, Switzerland

IUCN (2015) International Union for Conservation of Nature. Red list of threatened species. Version 2014.3. http://www.iucnredlist.org/. Accessed November 2014 
JRC-IES (2012) The International Reference Life Cycle Data System (ILCD) Handbook (online version). http://eplca.jrc.ec.europa.eu/? page id=86. Accessed March 2015

Kefford BJ, Zalizniak L, Dunlop JE, Nugegoda D, Choy SC (2010) How are macroinvertebrates of slow flowing lotic systems directly affected by suspended and deposited sediments? Environ Pollut 158:543-550

Koellner T, Scholz RW (2007) Assessment of land use impacts on the natural environment. Part 1: an analytical framework for pure land occupation and land use change. Int J Life Cycle Assess 12:16-23

Koellner T, Baan L, Beck T, Brandão M, Civit B, Goedkoop M, Margni M, Milà i Canals L, Muller-Wenk R, Weidema B, Wittstock B (2012) Principles for life cycle inventories of land use on a global scale. Int J Life Cycle Assess 18:1203-1215

Koellner T, Baan L, Beck T, Brandão M, Civit B, Margni M, Milà i Canals L, Saad R, Maia de Souza D, Muller-Wenk R (2013) UNEP-SETAC guideline on global land use impact assessment on biodiversity and ecosystem services in LCA. Int J Life Cycle Assess 18:1188-1202

Kosmas C, Danalatos NG, López-Bermúdez L, Diaz MAR (2012) The effect of land use on soil erosion and land degradation under Mediterranean conditions. In: Geeson NA, Brandt CJ, Thornes J (eds) Mediterranean desertification. A mosaic of processes and responses. John Wiley \& Sons, West Sussex

La Marche L, Lettenmaier DP (2001) Forest road effects on flood flows in the Deschutes River Basin, Washington. Earth Surf Process Landforms 26:115-134

Lima MIP, Santo FE, Ramos AM, de Lima JLMP (2013) Recent changes in daily precipitation and surface air temperature extremes in mainland Portugal, in the period 1941-2007. Atmos Res 127:195-209

Lindstrom MJ, Nelson WW, Schumacher TW (1992) Quantifying tillage erosion rates due to moldboard plowing. Soil Tillage Res 24:243-255

Luce JJ, Steele R, Lapointe MF (2010) A physically based statistical model of sand abrasion effects on periphyton biomass. Ecol Model 221:353-361

Meyer LD, Dabney SM, Harmom WC (1995) Sediment-trapping effectiveness of stiff-grass hedges. Trans ASAE 38:809-815

Michelsen O (2008) Assessment of land use impact on biodiversity. Proposal of a new methodology exemplified with forestry operation in Norway. Int J Life Cycle Assess 13:22-31

Milà i Canals L, Bauer C, Depestele J, Dubreuil A, Knuchel RF, Gaillard G, Michelsen O, Muller-Wenk R, Rydgren B (2007) Key elements in a framework for land use impact assessment within LCA land use in LCA. Int J Life Cycle Assess 12:5-15

Milà i Canals L, Rigarlsford G, Sim S (2012) Land use impact assessment of margarine. Int J Life Cycle Assess 18:1265-1277. doi:10.1007/ s11367-012-0380-4

Montgomery DR (2007) Soil erosion and agricultural sustainability. Proc Natl Acad Sci U S A 104:13268-13272

Notebaart B, Govers G, Gobin A, Verlinden G (2005) Eindrapport: verbetering kwantificering van diffuse verontreiniging van oppervlaktewater met metalen uit erosie. Vlaamse Milieumaatschappij

Núñez M, Antón A, Muñoz P, Rieradevall J (2012) Inclusion of soil erosion impacts in Life Cycle Assessment on a global scale: application to energy crops in Spain. Int J Life Cycle Assess 18:755-767

Panagos P, Meusburger K, Ballabio C, Borrelli P, Alewell C (2014) Soil erodibility in Europe: a high-resolution dataset based on LUCAS. Sci Total Environ 479-480:189-200

Parkhill KL, Gulliver JS (2002) Effect of inorganic sediment on wholestream productivity. Hydrobiologia 472:5-17

Pimenta MT (1998) Directrizes para a aplicação da equação universal de perda dos solos em SIG, Parâmetro de cultura $\mathrm{C}$ e parâmetro de erodibilidade do solo K. [Guidelines for the implementation of the universal equation of soil loss in GIS. C and K parameters. Instituto da Água/Direção de Serviços de Recursos Hídricos, Lisboa
Pimentel D, Burgess M (2013) Soil erosion threatens food production. Agriculture 3:443-463

Pimentel D, Harvey C, Resusodarmo P, Sinclair K, Kurz D, McNair M, Crist S, Fitton L, Saffouri R, Blair R (1995) Environmental and economic costs of soil erosion and conservation benefits. Science 267:1117-1123

Quinteiro P, Dias AC, Ridoutt BG, Arroja L (2014) A framework for modelling the transport and deposition of eroded particles towards water systems in a Life Cycle Inventory. Int J Life Cycle Assess 19: $1200-1213$

Quinteiro P, Dias AC, Araújo A, Pestana JLT, Ridoutt BG, Arroja L (2015a) Suspended solids in freshwater systems: characterisation model describing potential impacts on aquatic biota. Int J Life Cycle Assess 20(9):1232-1242

Quinteiro P, Dias AC, Silva M, Ridoutt B, Arroja L (2015b) A contribution to the environmental impact assessment of green water flows. J Clean Prod 93:318-329

Reap J, Roman F, Duncan S, Bras B (2008) A survey of unresolved problems in Life Cycle Assessment. Part 2: impact assessment and interpretation. Int J Life Cycle Assess 13:374-388

Reinhard J, Zah R (2009) Global environmental consequences of increased biodiesel consumption in Switzerland: consequential Life Cycle Assessment. J Clean Prod 17:S46-S56

Renard KG, Foster GR, Weesies GA, Mc Cool DK, Yoder DC (1997) Predicting soil erosion by water: a guide to conservation planning with the Revised Universal Soil Loss Equation (RUSLE). Agricultural Handbook No. 703, United States Department of Agriculture

Richardson J, Jowett IG (2002) Effects of sediment on fish communities in East Cape streams, North Island, New Zealand. New Zeal J Mar Freshw Res 36:431-442

Saad R, Margni M, Koellner T, Wittstock B, Deschênes L (2011) Assessment of land use impacts on soil ecological functions: development of spatially differentiated characterisation factors within a Canadian context. Int J Life Cycle Assess 16:198-211

Saad R, Koellner T, Margni M (2013) Land use impacts on freshwater regulation, erosion regulation, and water purification: a spatial approach for a global scale level. Int J Life Cycle Assess 18:1253-1264

Schindler BDE, Hilborn R (2015) Prediction, precaution, and policy under global change. Science 347(6225):953-954

Schmidt JH (2008) Development of LCIA characterisation factors for land use impacts on biodiversity. J Clean Prod 16:1929-1942

Slattery MC, Burt TP (1997) Particle size characteristics of suspended sediment in hillslope runoff and stream flow. Earth Surf Process Landforms 22:705-719

SNIRH (2015) Dados de base. [Database.]. Sist. Nac. Informação Recur. Hídricos., Lisboa, Port. http://snirh.apambiente.pt/. Accessed December 2014

Struijs J, Beusen A, de Zwart D, Huijbregts M (2010) Characterisation factors for inland water eutrophication at the damage level in Life Cycle Impact Assessment. Int J Life Cycle Assess 16:59-64

Takken I, Beuselinck L, Nachtergaele J, Govers G, Poesen J, Degraer G (1999) Spatial evaluation of a physically-based distributed erosion model (LISEM). Catena 37:431-447

Van Oost K, Govers G, Desmet P (2000) Evaluating the effects of changes in landscape structure on soil erosion by water and tillage. Land Ecol 15:577-589

Van Rompaey JJV, Verstraeten G, Van Oost K, Govers G, Poesen J (2001) Modelling mean annual sediment yield using a distributed approach. Earth Surf Process Landforms 1236:1221-1236

Verstraeten G (2006) Regional scale modelling of hillslope sediment delivery with SRTM elevation data. Geomorphology 81:128-140

Verstraeten G, Van Oost K, Van Rompaey A, Poesen J, Govers G (2002) Evaluating an integrated approach to catchment management to reduce soil loss and sediment pollution through modelling. Soil Use Manag 18:386-394 